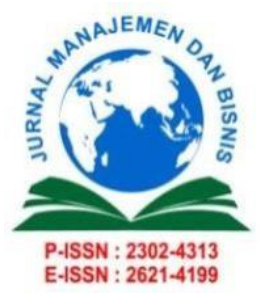

\author{
Jurnal Manajemen dan Bisnis \\ Vol. 10, No. 2, December 2021, pp. 80-90 \\ Sekolah Tinggi Ilmu Ekonomi Indragiri (STIE-I) Rengat \\ https://journal.stieindragiri.ac.id/index.php/jmbi/issue/view/20
}

\title{
ANALYSIS OF INNOVATION STRATEGIES TO INCREASE THE COMPETITIVE ADVANTAGES OF ULOS PRODUCTS IN PEMATANGSIANTAR CITY
}

\author{
Fitria Halim $^{1)}$, Sherly ${ }^{2)}$, Ernest Graces), Darwin Lie ${ }^{4)}$, Acai Sudirman 5) \\ 1) 2) 4) 5) Management Study Program, Sekolah Tinggi Ilmu Ekonomi Sultan Agung, ${ }^{3)}$ Accounting Study \\ Program, Sekolah Tinggi Ilmu Ekonomi Sultan Agung \\ fitriahalim2839@stiesultanagung.ac.id ${ }^{1)}$ sherly@ stiesultanagung.ac.id ${ }^{2)}{\text { ernestgrace@ stiesultanagung.ac.id }{ }^{3)}}^{3}$ \\ darwin@ stiesultanagung.ac.id ${ }^{4)}$ acaivenly@ stiesultanagung.ac.id ${ }^{5)}$ \\ Submited: 2021.10.10 Reviewed: 2021.11.20 Accepted: 2021.12.31 \\ https://doi.org/10.34006/jmbi.v10i2.308
}

\begin{abstract}
One of the production sectors that has become the flagship product of Pematangsiantar City is ulos cloth. Ulos cloth is a typical woven fabric of the Batak community developed for generations in North Sumatra, one of which is the city of Pematangsiantar. This study aims to explore various information related to the number of ulos craftsmen in Pematangsiantar city to facilitate the government in grouping these ulos craftsmen and as a first step to formulate an innovation strategy for the development of creative ulos fabric production to be able to develop superior products armed with knowledge. knowledge, creativity, innovation and being able to create jobs for the community. This type of research is qualitative with a one-shot model, namely an approach model by conducting one-time data collection on an object of research. The research subjects taken in this study were ulos craftsmen spread across eight sub-districts of Pematangsiantar City. The analysis was carried out in eight sub-districts in Pematangsiantar City. Data collection techniques using observation, interviews and questionnaires, field notes and documentation. The results of the study concluded that the innovation strategy applied by the ulos fabric craftsmen was not optimal, this was due to the limited capacity and opportunity to innovate, the ulos craftsmen experienced problems in making product innovations related to technological limitations caused by limited investment capital to buy new machines or equipment. to improve production processes and limited human resources who can operate new machines or make innovations that take advantage of technological developments.
\end{abstract}

Keywords: Innovation, Competitive Advantage, Ulos Products

\section{INTRODUCTION}

The improving economic growth of Pematangsiantar City is in line with the improving regional and national economy, which has a significant influence on local revenue and is supported by the increasing development of MSMEs. The majority of business actors who develop in Pematangsiantar City are micro and small scale. Several micro and small businesses located in all subdistricts are still not optimal in entrepreneurship so that it is not uncommon for some of these business actors to experience setbacks in entrepreneurship and eventually close their businesses. Pematangsiantar City is one of the cities in North Sumatra Province, and the second largest city in the province after Medan. Due to the strategic location of Pematangsiantar, it is crossed by the Trans Sumatra Highway.253,500 soul (Statistik, 2019). Pematangsiantar City also has small, medium and even large-scale industrial sectors and trade centers for traditional and modern markets. This condition 
is supported by the position of Pematangsiantar City as the Center. Regional Activities (PKW) based on the Regional Spatial Plan (RTRW) of North Sumatra Province (Statistik, 2017).

The ulos weaving industry in Pematangsiantar is one of the economic activities carried out by many people, because it can be done only by having good weaving skills and does not have to have special education. The majority of these industry players are housewives who weave to increase their economic income, fulfill their daily needs and help their husbands earn a living for their survival without leaving their homes and children. Currently, the raw materials for making ulos can be purchased and reached by weavers where the supplier sells the ulos yarn with a credit system and profit sharing between weaving entrepreneurs and yarn sellers, this condition is very supportive to be able to maintain their business.

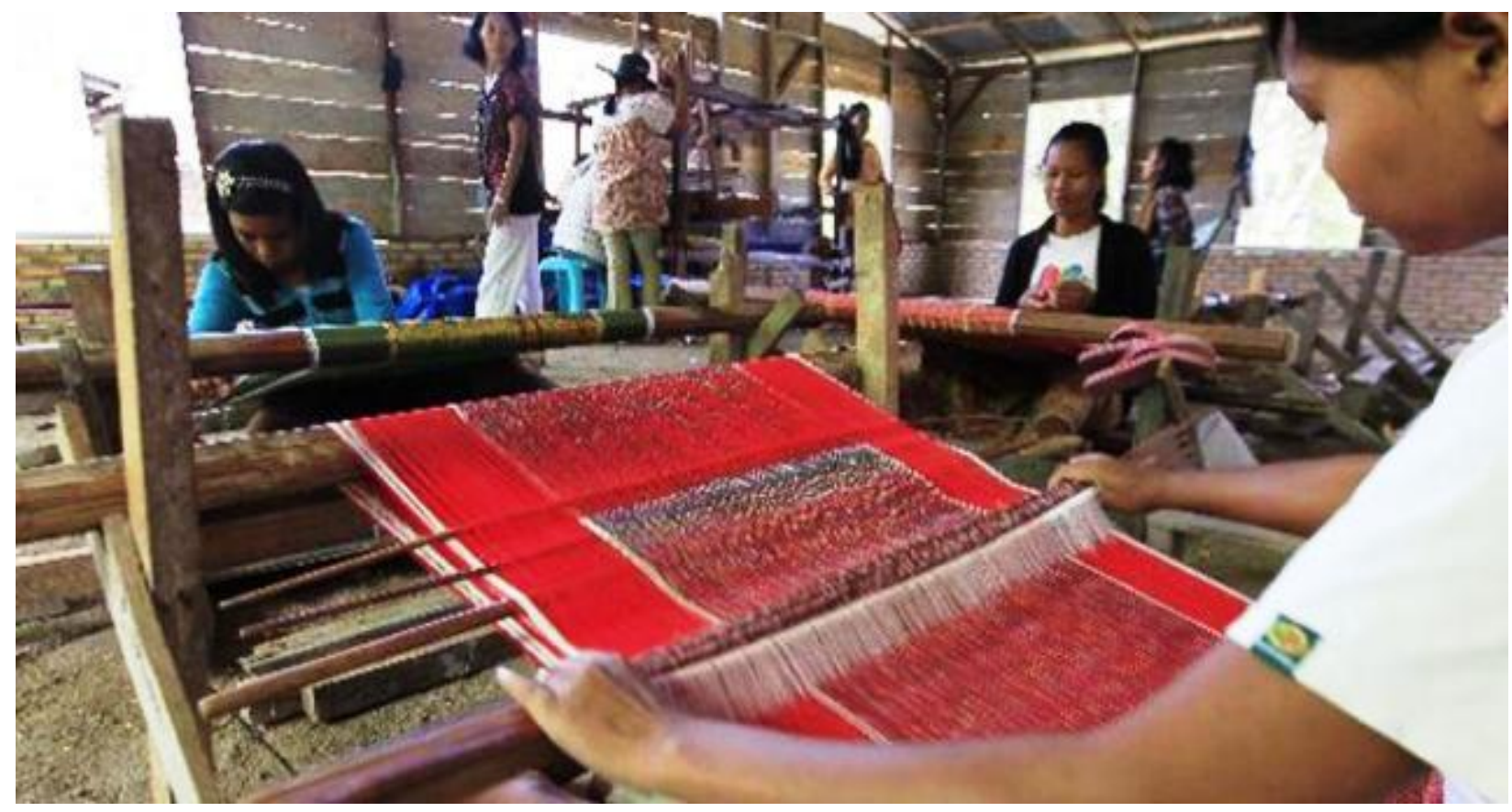

Figure 1.Ulos Pictures (Source: (Gee, 2014))

One of the superior products typical of Pematangsiantar City is Ulos cloth, one of the local MSMEs based on Local Economic Development (LED). Currently ulos cloth is used as official clothing in several institutions, both private and government, although not entirely using the service made from ulos cloth (Nurmansyah, 2012). One way to improve the regional economy is to support local entrepreneurs to produce innovative works and compete not only on a national scale, but also internationally. In enhancing their business competitiveness, ulos cloth business actors also often experience obstacles in product innovation (Ayesha et al., 2021). MSME product innovation is related to technological limitations caused by many factors, including limited investment capital to buy new machines or improve the production process, limited information regarding technological developments or new production machines and tools, and limited human resources available. able to operate new machines or make innovations in products and production processes. Innovation can be done by starting from various strategies (Sumarwan, 2010); including creating unique new products is one of the practical innovation strategies. In addition, it can also develop products that are already on the market to become more valuable, for example by improving quality, improving the appearance of the packaging to make it more attractive. Utilizing modern technology in the company's production and operational processes to produce higher quality products. Improve the skills and knowledge of workers to produce more innovative products, Provide services to consumers so that consumers are loyal and remain loyal to increase sales (Sutisna, Adhikara dan Huseini, 2019).

A company with a competitive advantage can create higher economic value for stakeholders, customers and suppliers compared to competitors. The company strives to maintain its competitive 
advantage by innovating processes, product features, and ways of transacting. Competition is a fundamental challenge of business strategy. To survive and achieve success, companies must outperform competitors in many different ways. Companies must offer customers higher value by offering higher quality and convenience at relatively lower prices than competitors. Companies must be more attractive to suppliers and distributors, besides that they must also compete in attracting investors' attention. This is done to create high competitiveness to encourage a sustainable competitive advantage. Competitive advantage is the center of the company's performance in market competition. The innovation strategy is for competitive advantage consisting of cost advantage, differentiation and customer focus (Michael, 1985).

The urgency of competitive advantage in business is seen when a business can survive in various contexts of changing internal and external environments (Distanont \& Khongmalai, 2020). This is important to be studied further, considering that the role of competitive advantage has a major impact on business sustainability in the future (Guleş et al., 2015). Therefore, it is important to know the fundamental factors that drive competitive advantage from the internal environment itself. Research result (Lee et al., 2019), concluded that it is crucial to increase the entrepreneurial spirit channeled in the form of metacognition through entrepreneurship education. This cannot be separated from the cultivation of entrepreneurship from the will to run a business. Therefore, each business actor has a different strategy in achieving competitive advantage, although there may be innovations in products, services, processes, programs, technology or organizational structures, the company's capabilities are needed to achieve product or service innovation to achieve competitive advantage (Limaj \& Bernroider, 2019). This study tries to use indicators of competitive advantage consisting of superior efficiency, superior quality and customer responsibility. We believe and believe, if the three aspects of competitive advantage can be managed optimally, then we hope that it will encourage high competitiveness for ulos craftsmen in Pematangsiantar City, Indonesia.

The importance of digging up various information related to the number of ulos craftsmen in Pematangsiantar City is the first step for researchers to formulate what strategies can develop ulos product innovations to be more creative. This aims to present ulos products as superior products in Pematangsiantar City to create additional jobs for the community in the current pandemic situation. The urgency of this research is to provide an overview of the innovation strategies that ulos craftsmen can apply to increase the competitive advantage of ulos products as local products that have the characteristics of Pematangsiantar City, Indonesia to compete with other products in a very competitive business environment. competitive, Then with this article, it is hoped that it can provide input in the form of recommendations from research results to local governments in making policies related to the competitiveness of Ulos craftsmen SMEs and other business units.

\section{RESEARCH METHODOLOGY}

\section{RESEARCH SITES}

The research plan is carried out in January 2021 to July 2021. The selection of locations is adjusted to the number of ulos craftsmen in each sub-district in East Siantar, West Siantar, North Siantar, South Siantar, Siantar Marihat, Siantar Martoba, Siantar Sitalasari, Siantar Marimbum .

\section{TYPES OF RESEARCH}

This research was conducted with a qualitative approach with a one shot model, namely the approach model by conducting one-time data collection on an object of research (Arikunto, 2014). The research design is a field study and literature study. This research will formulate an information model of Ulos product innovation strategy to increase competitive advantage in Pematangsiantar City. 


\section{POPULATION AND SAMPLE}

The population in this study was sourced from primary and secondary data, namely the total number of ulos craftsmen in Pematangsiantar city obtained through observations and documentation in the field, totaling 197 business units, all of which were sampled in this study. Determination of the sample using purposive sampling technique, which is then determined using the slovin formula (N/1 $+(\mathrm{N} x \mathrm{e} 2)$, so the number of samples used is 132 ulos craftsmen.

\section{DATA ANALYSIS}

The flow of activities above can be described that the four main types of activities namely data collection, data reduction, data display, and data verification/conclusion (Sugiyono, 2012). Data reduction in research will be carried out by grouping the collected data according to the aspects of the research problem. This data reduction was done to sharpen and organize field data obtained from observations, interviews, documentation, and field notes. Thus the conclusions can be verified to be used as research findings on the problem under study. The reduced data is then presented (displayed) in a description according to the research aspects. The presentation of this data is intended to make it easier for researchers to interpret the data and draw conclusions. Based on the research aspect,

\section{RESULTS AND DISCUSSION}

\section{RESPONDENT DESCRIPTION}

This study used 132 respondents who were none other than Ulos craftsmen in Pematangsiantar City. Overall, the respondents who filled out the questionnaire were 67 men $(50.76 \%)$ and 65 women (49.24\%). The average age of ulos craftsmen is in the range of 21-30 years as many as 20 people (15.15\%), ages with a range of 31-40 years as many as 55 people (41.67\%), ages with a range of 41-50 years as many as 30 ( 22.73\%), and age ranged from 51-60 as many as 27 people $(20.45 \%)$. As for the education level of the ulos craftsmen as a whole, 122 high school graduates $(92.42 \%)$ and 10 graduates $(7.58 \%)$. The overall business description can be explained in the following image:

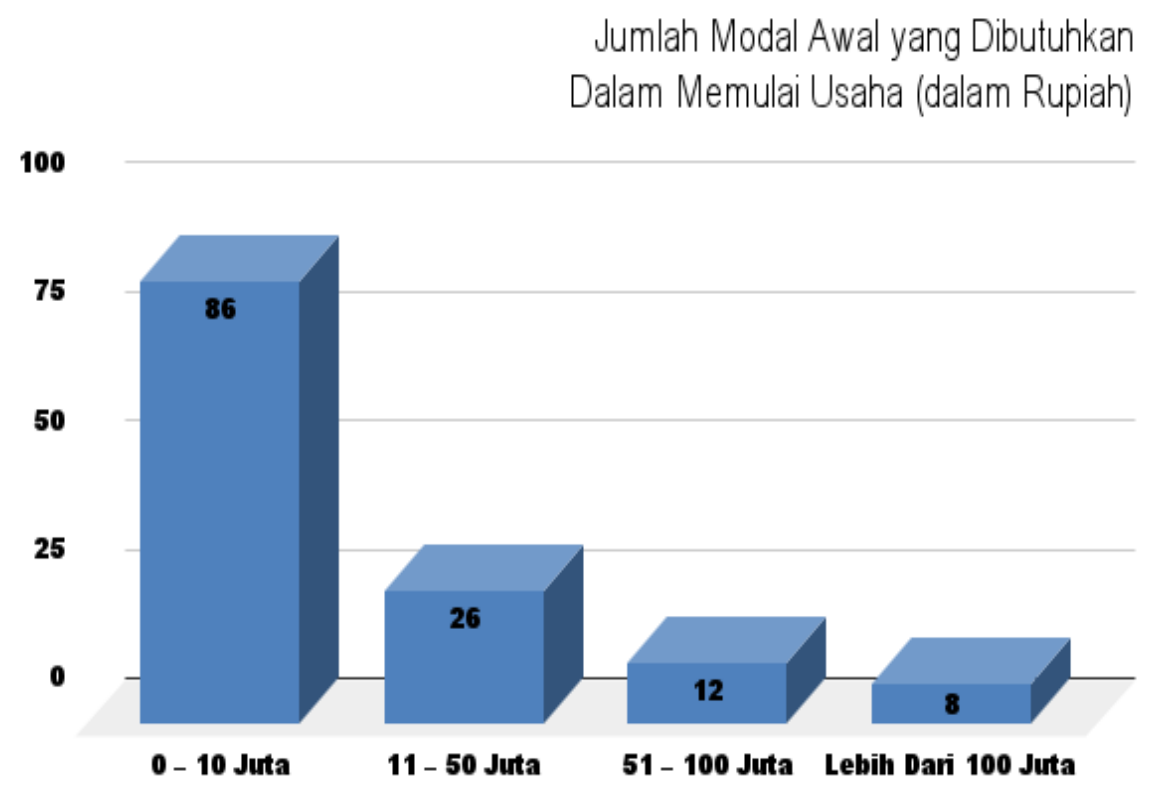

Figure 2. Amount of Initial Capital Required

Source: Research Results (2021) 


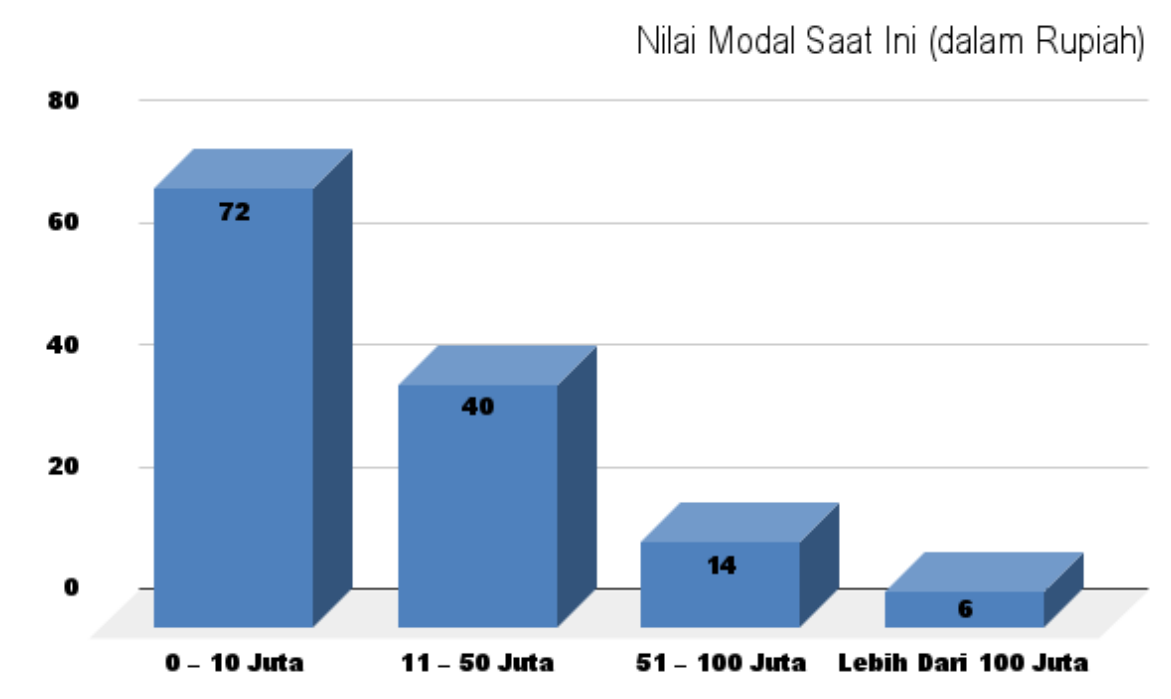

Figure 3. Current Capital Value

Source: Research Results (2021)

Based on Figure 2 above, it is known that as many as 86 ulos craftsmen have initial capital to start their business in the range of 0-10 million. Then as many as 26 ulos craftsmen have initial capital to start their business in the range of 11-15 million. Furthermore, as many as 12 ulos craftsmen have initial capital to start their business in the range of 51-100 million. Furthermore, as many as 18 ulos craftsmen have initial capital to start their business in the range of more than 100 million. This indicates that the majority of ulos craftsmen have low initial capital in running their business. This condition can be seen from traditional looms and minimal labor requirements, so that the initial capital required is not too large. Based on Figure 3 above, It is known that 72 ulos craftsmen have a current capital value in the range of $0-10$ million and as many as 40 ulos craftsmen have a current capital value in the range of 11-50 million. Then it is also known that as many as 14 ulos craftsmen have a current capital value in the range of 51-100 million and 6 ulos craftsmen have a current capital value of more than 100 million. This indicates that the majority of ulos craftsmen did not experience significant capital development for their business. Limited market access and limited availability of resources that support business development such as equipment and supplies and limited initial capital impact the pace of business development.

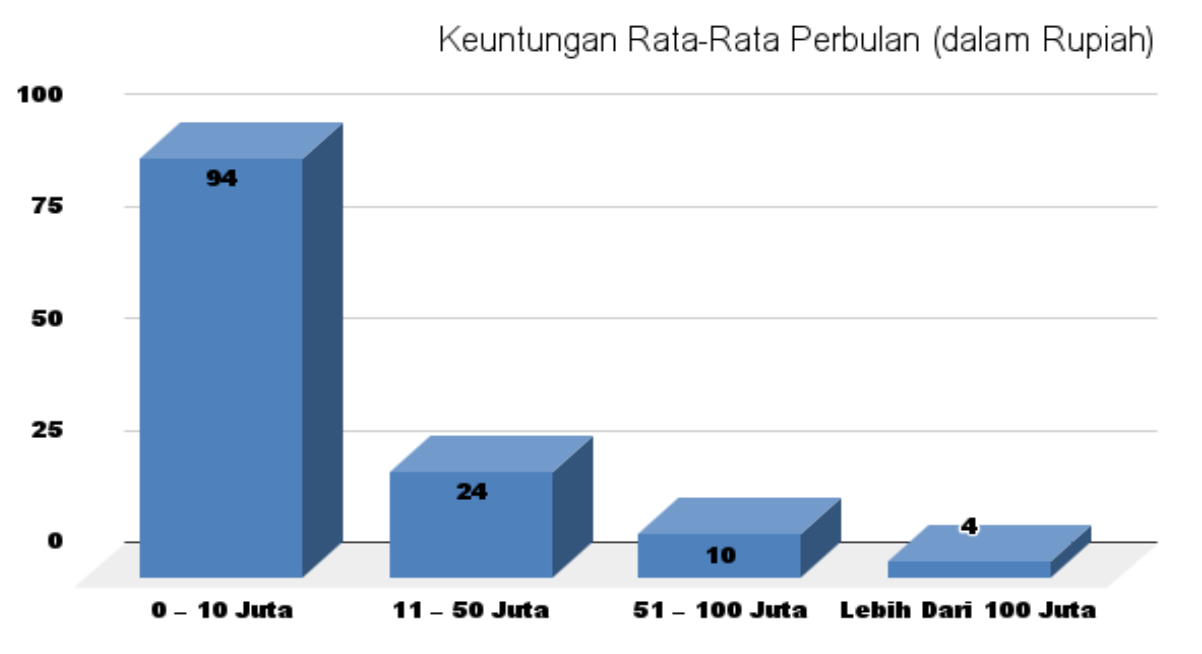

Figure 4. Monthly Average Profit (in Rupiah)

Source: Research Results (2021) 


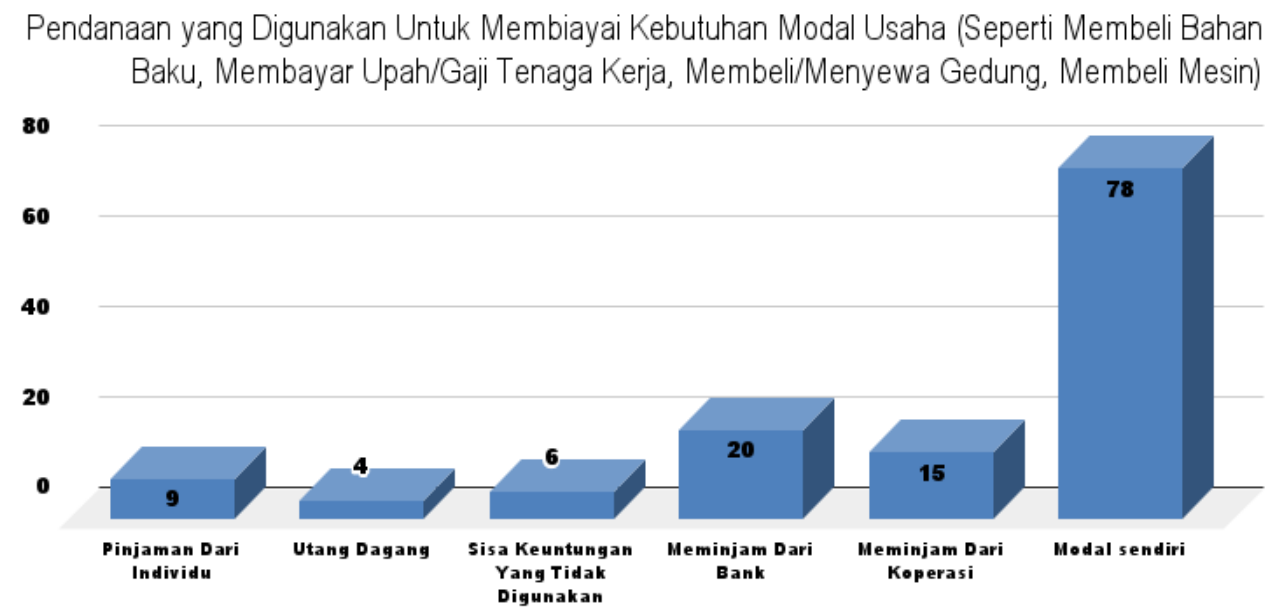

Figure 5. Funding Used to Financing Business Capital Needs Source: Research Results (2021)

Based on Figure 4 above, it is known that as many as 94 ulos craftsmen have profits in the range of 0-10 million and as many as 24 ulos craftsmen have profits in the range of 11-50 million. Furthermore, as many as 10 ulos craftsmen have profits in the range of 51-100 million and as many as 4 ulos craftsmen have profits in the range of more than 100 million. The graph results show that the majority of ulos craftsmen have profits that are still small in amount compared to profits that exceed 100 million. This situation is in line with the level of initial capital owned, which is still small and the absence of growth in the value of the capital invested in the business. Limited access to capital and markets makes it difficult for ulos craftsmen to develop their businesses. especially in the current pandemic situation, the results of ulos crafts have decreased significantly. Therefore, this condition causes the profits of the average ulos craftsman to remain low. Based on Figure 5 above, it is known that as many as 78 ulos craftsmen have business capital funding that comes from their capital, as many as 15 ulos craftsmen have business capital funding from cooperative loans, as many as 20 ulos craftsmen have business capital funding from bank loans. 6 ulos craftsmen have business capital funding that comes from residual profits, as many as 4 ulos craftsmen have business capital funding from trade debts, and 9 ulos craftsmen have business capital funding from individual loans.

\section{Sistem Penjualan Produk}

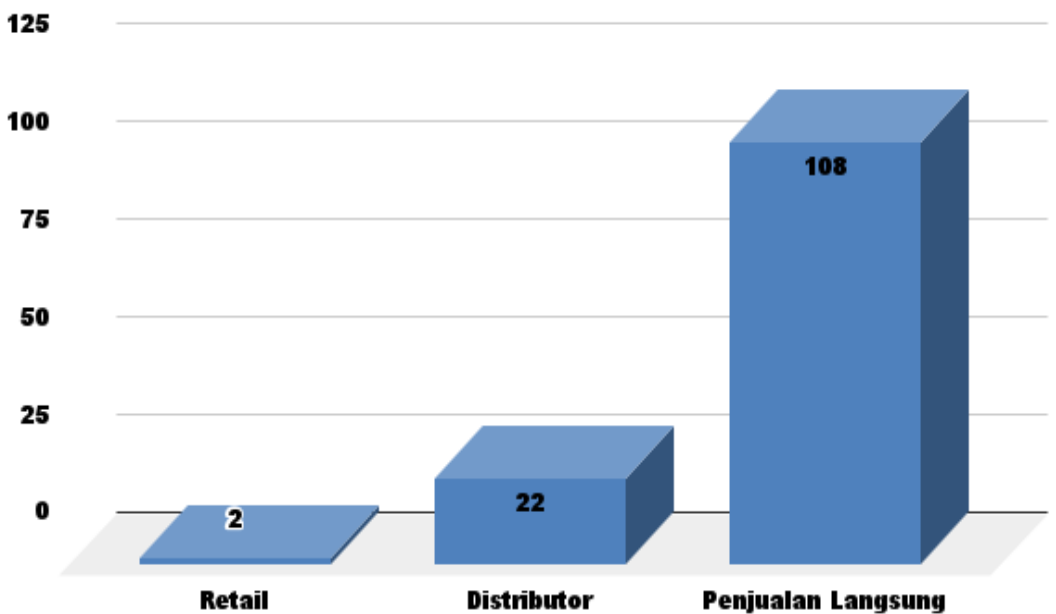

Figure 6. Product Sales System

Source: Research Results (2021) 
Tingkat Persaingan Usaha Produk Utama

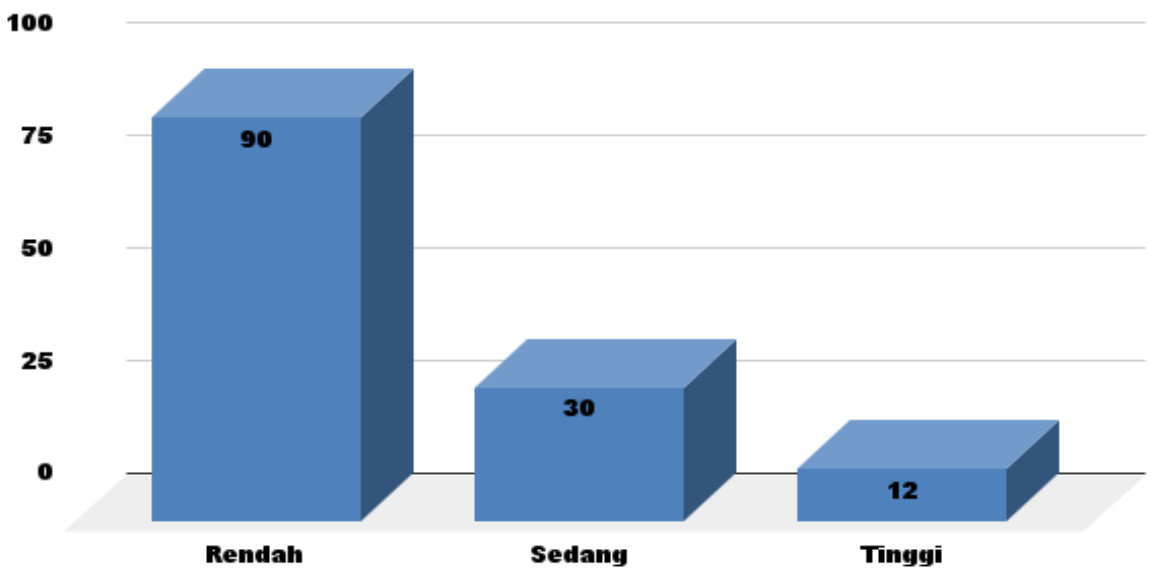

Figure 7. Level of Business Competition

Source: Research Results (2021)

Based on Figure 6 above, it is known that 108 ulos craftsmen have a product sales system oriented to direct sales, 22 ulos craftsmen have a distributor-oriented product sales system and as many as 2 ulos craftsmen have a retail-oriented product sales system. Based on Figure 7 above, it is known that 108 ulos craftsmen have a product sales system oriented to direct sales, 22 ulos craftsmen have a distributor-oriented product sales system and as many as 2 ulos craftsmen have a retail-oriented product sales system. The results of data analysis with graphs conclude that the majority of business competition levels of business actors are at a low level.

\section{DISCUSSION}

Human resources are the most important aspect of doing business. From the research results, the majority of knowledge and skills are passed down from the previous generation. Therefore, in terms of creativity they are less able to develop their abilities (Djajasinga et al., 2021). In improving the competitiveness of their business, every Ulos business actor also often experiences obstacles in product innovation. Product innovation of ulos business actors is related to technological limitations caused by many factors including, limited investment capital to purchase new machines or to improve the production process, limited information regarding technological developments or new production machines and tools, and limitations HR who can operate new machines or make innovations in products and production processes (Siregar et al., 2020). To increase product competitiveness, ulos business actors must be more creative and innovative in producing goods (Afwa et al., 2021). For their products to be noticed, ulos business actors must offer innovative products different from other similar products (Sudirman et al., 2021)

The ulos weaving industry in Pematangsiantar is one of the economic activities carried out by many people, because it can be done only by having good weaving skills and does not have to have special education. The majority of these industry players are housewives who weave to increase their economic income, fulfill their daily needs and help their husbands earn a living for their survival without leaving their homes and children. Currently, the raw materials for making ulos can be purchased and reached by weavers where the supplier sells the ulos yarn with a credit system and profit sharing between weaving entrepreneurs and yarn sellers, this condition is very supportive to be able to maintain their business. However, the tendency of suppliers like this can also harm ulos entrepreneurs because suppliers are the determinants of the price of the ulos yarn so that it can also threaten the sustainability of this business. In addition, most Ulos business actors have limitations in implementing marketing channels to market the Ulos products they produce. The lack of innovation in knowledge aspects related to the use of E-Commerce causes them to distribute their products traditionally by selling to ulos agents who have a limited price benchmark. On the other hand, the use 
of promotional media through social media access has also not been implemented optimally so that they do not have the opportunity to educate consumers regarding the products they will market. the majority of ulos business actors have limitations in implementing marketing channels to market the ulos products they produce. The lack of innovation in knowledge aspects related to the use of ECommerce causes them to distribute their products traditionally by selling to ulos agents who have a limited price benchmark. On the other hand, the use of promotional media through social media access has also not been implemented optimally so that they do not have the opportunity to educate consumers regarding the products they will market. the majority of ulos business actors have limitations in implementing marketing channels to market the ulos products they produce. The lack of innovation in knowledge aspects related to the use of E-Commerce causes them to distribute their products traditionally by selling to ulos agents who have a limited price benchmark. On the other hand, the use of promotional media through social media access has also not been implemented optimally so that they do not have the opportunity to educate consumers regarding the products they will market (Purnomo et al., 2020)

In addition, the competitive advantage of ulos business actors in terms of superior efficiency is also still not optimal. This can be seen when we conducted interviews with several Ulos business actors who lacked knowledge regarding the efficient use of budgets which was illustrated by choosing the right technology to cut costs. In addition, the next problem for Ulos business actors is the lack of knowledge of MSME entrepreneurs about good business management. Often, ulos business actors only focus on producing goods, without considering how their business expansion strategy is even bigger. As a result, ulos business actors are hampered in long-term business development. Their business was run but did not grow and the turnover did not increase. If we trace back the initial capital and working capital have been spent a lot, but the turnover entered in the business is much less, which makes the business run in place or even go out of business. Ulos business actors using the online concept seem to be a new thing for MSME actors in Indonesia. But don't get me wrong, even though as a ulos business actor you don't know the concept of online, rest assured that there are lots of customers who buy products if the ulos business actor wants to go online. The plus value of online ulos business actors is that they don't require a lot of capital to open an online business, and getting customers is also getting easier. This is because there is no need to rent a stall or a place to run wares. In addition, customers are also easier to find their merchandise.

Furthermore, the competitive advantage of ulos business actors in terms of superior quality is still not optimal. In this case, business actors must truly understand consumers' perspective so that the products and services produced can truly provide solutions to the problems they face and have an impact on purchases. But in fact, existing business actors only focus on selling expertise, copying what already exists, and producing products that they think are "good" without first analyzing market needs. Finally, because the products and services being traded are guided by the seller's point of view rather than the market's or buyer's point of view, so that the sale becomes less desirable or which at first is still in demand but along with changes and lack of innovation, The market tends to look for substitute products that are more capable of meeting their needs. Based on the research results by Senk, et al., (2010), developing and marketing products requires adequate skills and information so that initiatives emerge to create new products to maintain business growth. It is better if the government can partner or collaborate with educational institutions (eg universities) as an extension of the hand to dig up information related to market needs through interviews, distributing questionnaires, or digital media so that business actors can adjust the products sold to market demand. To develop and market products, adequate skills and information are needed to emerge to create new products to maintain business growth. It is better if the government can partner or collaborate with educational institutions (eg universities) as an extension of the hand to dig up information related to market needs through interviews, distributing questionnaires, or digital media so that business actors can adjust the products sold to market demand. To develop and market products, adequate skills and information are needed to emerge to create new products to maintain business growth. It is better if the government can partner or collaborate with educational institutions (eg universities) as an extension of the hand to dig up information related to market needs through interviews, distributing questionnaires, or digital 
media so that business actors can adjust the products sold to market demand.

Then, the competitive advantage of ulos business actors in terms of customer responsibility is still not optimal. Ulos business actors in Pematangsiantar City so far have tried to carry out a product image strategy to consumers who want to buy with several choices of available goods and services. The purpose of the product image strategy is so that consumers have an idea about the type of product or service they want. Promotion and product image need to get more serious attention by MSME actors in Pematangsiantar City, especially in determining the chosen marketing strategy that will penetrate the target market. Moreover, the conditions of increasingly fierce competition, such as today, require the ability to seize market share faced by Ulos business actors themselves. This situation is no exception to be faced by all ulos business actors in Pematangsiantar City. Promotion and product image are activities carried out by ulos business actors in Pematangsiantar City to introduce products known by the wider community. Some of the problems faced by ulos business actors in Pematangsiantar City related to product promotion and image, namely the lack of product introduction carried out by ulos business actors in this case including promotion through local product exhibitions in collaboration with the Cooperatives, SMEs and Trade Offices, still lacking in utilize and manage promotions and product image through digital marketing media (eg the use of social media), and have not maximized word of mouth promotion.

\section{CONCLUSIONS AND SUGGESTIONS}

\section{CONCLUSION}

The study results concluded that the implementation of innovations in Ulos products is still not optimal due to several limitations related to traditional raw materials, tools and equipment, limited market access, and not optimal media for promotion of capital, which is still minimal knowledge about aspects of entrepreneurship. In terms of raw materials, suppliers can harm entrepreneurs because suppliers are price determinants so that they can threaten business continuity where the increase in raw material prices at certain times of course affects the selling price of the product. furthermore, the majority of ulos craftsmen still use traditional tools and equipment so that it is very unlikely to encourage production growth. The limitations of traditional tools and equipment are because they lack capital to buy or increase the number of production equipment. In terms of promotion and product image, product introduction includes promotion through local product exhibitions in collaboration with the Cooperatives, SMEs and Trade Offices, promotions using digital marketing media (eg social media), and word of mouth promotion is still rarely carried out by ulos business actors. . Then in terms of market access, ulos business actors in Pematangsiantar still have limited market access where the majority of their products are still offered in the local market. This is because most ulos business actors are still family businesses, so they still have a weak business network and the lack of ulos entrepreneurs who apply online marketing. Regarding limited knowledge about entrepreneurship, from the technical/production aspect, ulos business actors only produce products that they think are "good" without prior analysis of market needs. Location selection is also very simple and generally only chooses locations. which can only carry out production and sales activities, and the selection of equipment is more oriented towards low costs to maximize income without paying attention to the impact on the quality of the products produced. From the management aspect, business activities are only income-oriented and do not have a target to be achieved, for example whether to set profit targets, increase production volume, increase the number of employees, or open branches. In addition, from the financial aspect, Ulos entrepreneurs do not know how profit and loss conditions are experienced every day because they have never done financial management, and the owner's and business finances are not separated.

\section{SUGGESTION}

As a suggestion to increase innovation and competitive advantage of ulos business actors, the Pematangsiantar City Government should intervene in the procurement of these raw materials by forming a cooperative for ulos weaving entrepreneurs, so that each member can support each other in 
terms of procurement of raw materials related to business capital and also establish cooperatives. cooperation with suppliers both local and outside the region that can meet the needs of yarn supply for cooperative members. Then to overcome capital and infrastructure problems, the Government through the relevant agencies should be more proactive in offering loan products by directly listing potential businesses to get credit from the government. Furthermore, to enhance product promotion and image, Ulos craftsmen should be given assistance or willing to learn from the experiences shared by many local and national entrepreneurs and learn from various books, entrepreneurship websites or blogs, social networks, or through continuous and skill-oriented training seminars in terms of product promotion and image. Then, to optimize knowledge about aspects of entrepreneurship, from the technical/production aspect, the Government should be able to partner or collaborate with higher education institutions (eg universities) as an extension of the arm to dig up information related to market needs through interviews or distributing questionnaires,ulos businessmanin Pematangsiantar City, as well as facilitating business actors with banks regarding capital loans that will be converted to business equipment that can guarantee the creation of quality product outputs. From the management aspect, the government should assist the perpetratorsulos businessman through academics and professionals in making business plans through setting business targets and can help ulos businessmanto establish partnerships or build links from suppliers, customers, communities, and competitors to optimize their production activities. From a financial aspect, each actor should ulos businessman gain knowledge about performing financial management based on Financial Accounting Standards for Micro, Small and Medium Entities (SAK-EMKM).

\section{ACKNOWLEDGEMENT}

On this occasion, the writing team would like to express their deepest gratitude to the DRPM for the funding budget for the National Competitive Research Scheme for Beginner Lecturer Research in 2021. The writing team would also like to express their deepest gratitude to all parties involved in the research completion process. and writing of articles, to the Regional Planning and Management Agency (BAPPEDA) of Pematangsiantar City which has provided a research permit, the entire academic community of the Sultan Agung College of Economics and to the editorial team and reviewers of management and business journals managed by the Indragiri Rengat School of Economics which always provide constructive input to improve this article.

\section{REFERENCES}

Afwa, A., Djajasinga, N. D., Sudirman, A., Sari, A. L., \& Adnan, N. M. (2021). Raising the Tourism Industry as an Economic Driver. Proceedings of the 2nd Annual Conference on Blended Learning, Educational Technology and Innovation (ACBLETI 2020) Raising, 560(Acbleti 2020), $118-123$.

Arikunto, S. (2014). Prosedur Penelitian Suatu Pendekatan Praktik. Rineka Cipta.

Ayesha, I., Redjeki, F., Sudirman, A., Leonardo, A., \& Aslam, D. F. (2021). Behavior of Female Entrepreneurs in Tempe Small Micro Enterprises in Tasikmalaya Regency, West Java as Proof of Gender Equality Against AEC. Proceedings of the 2nd Annual Conference on Blended Learning, Educational Technology and Innovation (ACBLETI 2020), 560(Acbleti 2020), 124130.

Data, B. (2017). Kota Pematangsiantar. Profil Kota.

Distanont, A., \& Khongmalai, O. (2020). The Role of Innovation in Creating a Competitive Advantage. Kasetsart Journal of Social Sciences, 41(1), 15-21. https://doi.org/10.1016/j.kjss.2018.07.009

Djajasinga, N. D., Sulastri, L., Sudirman, A., Sari, A. L., \& Rihardi, L. (2021). Practices in Human Resources and Employee Turnover in the Hospitality Industry. Proceedings of the 2nd Annual Conference on Blended Learning, Educational Technology and Innovation (ACBLETI 2020) Practices, 560(Acbleti 2020), 113-117.

Gee. (2014). Tas Ulos Mulai Trend di Mahasiswa Siantar. Hetanews.

Guleş, H. K., Zerenler, M., Cagliyan, V., Karaboğa, K., \& Asst, R. (2015). The Effect of Market Orientation and Innovation Ability on Enterprise Performance: a Practice of Structural Equation 
Modelling Analysis: a Research on SMEs. European Scientific Journal, 11(10), 31-42.

Lee, J., Kim, D., \& Sung, S. (2019). The Effect of Entrepreneurship on Start-Up Open Innovation: Innovative Behavior of University Students. Journal of Open Innovation: Technology, Market, and Complexity, 5(4), 1-13. https://doi.org/10.3390/joitmc5040103

Limaj, E., \& Bernroider, E. W. N. (2019). The Roles of Absorptive Capacity and Cultural Balance for Exploratory and Exploitative Innovation in SMEs. Journal of Business Research, 94(October 2017), 137-153. https://doi.org/10.1016/j.jbusres.2017.10.052

Michael, P. (1985). Competitive Advantage: Creating and sustaining superior performance.

Nurmansyah, S. (2012). Lima Srikandi Partonun Ulos. Arsip Warta, 1.

Purnomo, A., Sudirman, A., Abdurrozzaq, H., Sudarso, A., Sahir, H. S., Salmiah, Mastuti, R., Chamidah, D., Koryati, T., \& Simarmata, J. (2020). Dasar-Dasar Kewirausahaan: Untuk Perguruan Tingi dan Dunia Bisnis (Cetakan 1). Yayasan Kita Menulis.

Senk, et al., 2010. Development of New Product/Process Development Procedure for SMEs. Journal Organizacija. Volume 43, No. 2: 76-85.

Siregar, R. T., Silitonga, H. P., \& Putri, J. A. (2020). Strategi Pengembangan Usaha Mikro, Kecil dan Menengah (UMKM) di Kota Pematangsiantar. Jurnal Konsep Bisnis Dan Manajemen, 6(2), $133-142$.

Statistik, B. P. (2019). Jumlah Penduduk menurut kelompok umur. 2019.

Sudirman, A., Halim, F., Nainggolan, A. B., Butarbutar, N., \& Sherly, S. (2021). Meninjau Hubungan Antara Penggunaan Media Sosial dan Orientasi Pasar Terhadap Kinerja Bisnis Sektor UMKM. Prosiding Seminar Nasional Ekonomi Dan Bisnis 2021 Universitas Muhammadiyah Jember, 165-179. https://doi.org/10.32528/psneb.v0i0.5165

Sugiyono. (2012). Metode Penelitian Bisnis. Alfabeta.

Sumarwan, U. (2010). Inovasi Produk, Kepuasan Konsumen dan Loyalitas Konsumen Sebagai Penentu Pertumbuhan Perusahaan. Sains Pemasaran Indonesia, 1.

Sutisna, Adhikara dan Huseini, M. (2019). Dua Faktor Penentu Keberhasilan sebuah Proses Inovasi. Jurnal Inovasi Bisnis 7, 1(7).

Undang-Undang Nomor 20 tahun 2008 tentang Usaha Mikro, Kecil, dan Menengah. 